Document downloaded from:

http://hdl.handle.net/10251/63962

This paper must be cited as:

Iborra Bernad, MDC.; García Segovia, P.; Martínez Monzó, J. (2015). Physico-Chemical and Structural Characteristics of Vegetables Cooked Under Sous-Vide, Cook-Vide, and Conventional Boiling. Journal of Food Science. 80(8):E1725-E1734. doi:10.1111/17503841.12950.

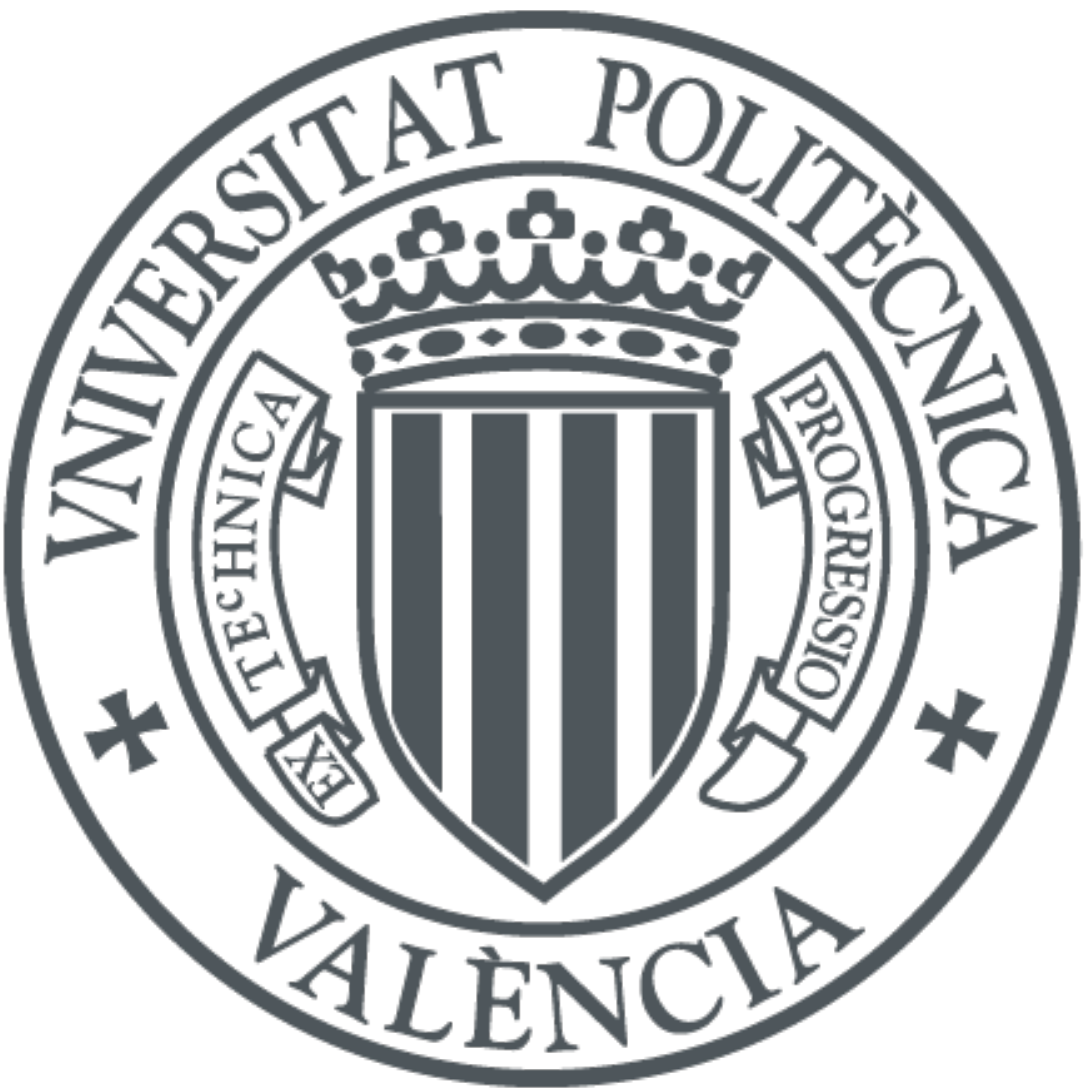

The final publication is available at

https://dx.doi.org/10.1111/1750-3841.12950

Copyright Wiley

Additional Information 


\section{PHYSICO-CHEMICAL AND STRUCTURAL CHARACTERISTICS OF}

5 VEGETABLES COOKED UNDER SOUS-VIDE, COOK-VIDE AND

6 CONVENTIONAL BOILING

7

8

9

C. Iborra-Bernad ${ }^{\mathrm{a}}$, P. García-Segovia ${ }^{\mathrm{a}}$, J. Martínez-Monzóa ${ }^{\text {* }}$. 
47

48

49

50

51

52

53

54

55

56

57

58

59

60

61

62

63

64

65

66

67

68

69

\section{ABSTRACT}

In this paper, physico-chemical and structural properties of cut and cooked purple-flesh potato, green bean pods and carrots have been studied. Three different cooking methods have been applied: traditional cooking (boiling water at $100{ }^{\circ} \mathrm{C}$ ), cook-vide (at $80^{\circ} \mathrm{C}$ and $90^{\circ} \mathrm{C}$ ) and sous-vide (at $80^{\circ} \mathrm{C}$ and $90^{\circ} \mathrm{C}$ ). Similar firmness was obtained in potato applying the same cooking time using traditional cooking $\left(100{ }^{\circ} \mathrm{C}\right)$, and cook-vide and sous-vide at $90{ }^{\circ} \mathrm{C}$, while in green beans and carrots the application of the sous-vide $\left(90^{\circ} \mathrm{C}\right)$ required longer cooking times than cook-vide $\left(90^{\circ} \mathrm{C}\right)$ and traditional cooking $\left(100{ }^{\circ} \mathrm{C}\right)$. Losses in anthocyanins (for purple-flesh potatoes) and ascorbic acid (for green beans) were higher applying traditional cooking. $\beta$-carotene extraction increased in carrots with traditional cooking and cook-vide $(p<0.05)$. Cryo-SEM micrographs suggested higher swelling pressure of starch in potatoes cells cooked in contact with water, such as traditional cooking and cook-vide. Traditional cooking was the most aggressive treatment in green beans because the secondary walls were reduced compared with sous-vide and cookvide. Sous-vide preserved organelles in the carrot cells, which could explain the lower extraction of $\beta$ carotene compared with cook-vide and traditional cooking. Sous-vide cooking of purple-flesh potato is recommended to maintain its high anthocyanin content. Traditional boiling could be recommended for carrots because increase $\beta$-carotenes availability. For green beans, cook-vide and sous-vide provided products with higher ascorbic acid content.

\section{KEYWORDS:}

Firmness, color, antioxidants, microstructure, cooking treatment.

\section{Practical Application}

Knowledge of the effects of various culinary treatments on vegetables allows processors to provide consumers with products with higher antioxidant contents and improved sensory properties, increasing the consumer satisfaction and product loyalty. 


\section{INTRODUCTION}

Vegetables play an important role in our diet due to elements such as fiber, water and phytochemical components. Many vegetables can be consumed raw or cooked. Cooking provides softer products, it gelatinizes the starch and the digestibility of the fiber is improved (Van Boekel and others 2010). Heat treatments reduce the firmness, mainly by the $\beta$-elimination reaction of pectic substances. In addition to depolymerization and solubilisation of pectic materials (Van Buggenhout and others 2009), the phytochemical compounds could be destroyed or leached into the water media during cooking treatments. The temperature reaches of about $100{ }^{\circ} \mathrm{C}$ and the presence of oxygen during the traditional cooking reduces antioxidant content in vegetables (Leskova 2006).

Therefore, a possible strategy to increase the final quality is the use of temperatures below $100{ }^{\circ} \mathrm{C}$ (reducing the damage of thermosensitive compounds) and reducing the oxidative process by diminishing the oxygen (Hui and others 2003). Sous-vide and cook-vide are two cooking treatments with a reduced access of the oxygen during cooking and the temperature applied is usually lower than $100{ }^{\circ} \mathrm{C}$. There are two main differences between both treatments. The first one is the presence of a pouch isolating the product of the cooking media in sous-vide, while in cook-vide products are in contact with the cooking media (water). The other one is the way of atmospheric conditions are modified. In sous-vide, samples are vacuum sealed in a pouch and the cooking media is maintained under atmospheric pressure (Baldwin 2012). Regarding cook-vide, products are cooked inside a cooker device with lower pressure causing the water boiling below $100{ }^{\circ} \mathrm{C}$ (García-Segovia and others 2007). In addition, the surface heat transfer coefficient could be higher in boiling water (cook-vide) than in liquid water (sous-vide) cooking at the same temperature. Some studies comparing different methods suggest that sous-vide provide cooked products with high sensory and nutritional values than others cooking methods, such as cooked potatoes (Stea and others 2007), cooked red cabbage (Iborra-Bernad and others 2014b) and chicory stems (Renna and others 2014). The presence of a pouch around the raw product before starting the cooking avoids the leaching out of the nutrients in the cooking water compared to other types of cooking treatments, such as boiling, steaming or microwaving (Charley and Weaver 1998). The use of sous-vide was largely used in the 
90's and recently, Baldwin (2012) reviewed the sous-vide treatment. The other treatment, the cook-vide, is a less studied treatment. Few reports using this low-pressure method have been conducted in meat, such as beef muscle (García-Segovia and others 2008), and in vegetables, such as potatoes, carrots, green bean and kailan-hybrid broccoli (García-Segovia and others 2007; Iborra-Bernad and others 2013a; IborraBernad and others 2013b; Martínez-Hernández and others 2013). Each cooking treatment can potentially damage the cell walls and membranes of vegetables causing different amounts of degradation in the antioxidant molecules contained in the cells. Some antioxidants are hydrophilic molecules, which could be leach out in the cooking water, such as vitamin $\mathrm{C}$, while others are hydrophobic molecules, such as $\beta$ carotene.

Regarding sensory quality, firmness and flavor are important properties to accept the intake of edible substances (Szczesniak and Kahn 1971). The heat transfer method and temperature affect the physicochemical properties of products such as firmness and antioxidant content. In the case of firmness, one of the main factors of the softness process is the degradation of the pectic materials (Van Buggenhout and others 2009). The knowledge of how each type of cooking treatment can affect each vegetable could be interesting to increase the quality of the ready-to-eat products. Therefore, studies applying different cooking treatments on the same product (Chiavaro and others 2006; Iborra-Bernad and others 2014a; Lachman and others 2013) are relevant to select the right culinary factors and increase the nutritional and sensorial quality offered to consumers.

The aim of the present work is to provide information about the most suitable cooking treatment for different vegetables and understand better how the vegetable cells and tissues are modified using different cooking treatments. 


\section{MATERIALS AND METHODS}

118

119

120

121

122

123

124

125

126

127

128

129

130

131

132

133

134

135

136

137

138

139

140

141

\subsection{MATERIALS}

Purple-flesh potatoes (Solanum tuberosum L. var. Vitelotte) provided by S.B.M. (Saveurs du Bout du Monde, Roscoff, France) were stored at $8^{\circ} \mathrm{C}$ up to 5 days before carrying on the test. Potatoes were cut into cylinders ( $15 \mathrm{~mm}$ in height $\times 20 \mathrm{~mm}$ in diameter) using a metal clay hole cutter.

Green bean pods (Phaseolus vulgaris L. cv. Estefania) were purchased from a local producer (S.A.T. Agricola Perichan, Valencia, Spain) one day before the experiments. The green beans were stored in the darkness at $5{ }^{\circ} \mathrm{C}$ until cooking process. The young pods of green beans $\mathrm{cv}$. Estefania are very straight, long $(22-24 \mathrm{~cm})$ and flattened. Before cooking, both ends of the pods were removed, and the green beans were cut in 6-7 cm long pieces.

Carrots (Daucus carota L. cv. Nantesa) were purchased from a local company (Agrícola de Villena, Alicante, Spain) one day before the experiments. The whole carrots were washed and cut into cylinders (15 $\mathrm{mm}$ in height $\times 20 \mathrm{~mm}$ in diameter) using a metal clay hole cutter. The condition to accept samples was the xylem tissue to be less than $10 \mathrm{~mm}$ diameter.

\subsection{COOKING METHODS}

Potato and carrot were cooked without blanching, while green beans were blanched for 1 min at $100{ }^{\circ} \mathrm{C}$ before the cooking treatment in order to reduce the cooking time to a less of an hour at $80^{\circ} \mathrm{C}$ and provide product with a firmness well-done but firm to the bite. After blanching, samples were cooled down in water with ice for ten seconds.

Three methods were applied in the study: traditional cooking (boiling water at $100{ }^{\circ} \mathrm{C}$ ) and two cooking treatments reducing the presence of the oxygen (sous-vide and cook-vide). Table 1 shows some characteristics of the cooking method used in this study. All treatments were carried out using distilled water for cooking to avoid interference of ions on the firmness and using the same device: Gastrovac ${ }^{\circledR}$ (International Cooking Concepts, Barcelona, Spain). This equipment consists of two elements: the main controller and the cooker. The controller contains a heating element and a vacuum pump. The 
142

143

144

145

146

147

148

149

150

151

152

153

154

155

156

157

158

159

160

161

162

163

164

165

166

167

temperature is controlled and monitored through a digital system connected to a thermocouple temperature sensor, which goes in the water bath (inside the cooker). To cook by cook-vide, products are placed in the basket (Fig 1. panel 2) and it is hooked in a handle for lifting the cooking basket. The pot is closed with a lid (3) that includes a handle. The basket is hung up avoiding contact with the heating media, which is heated to a desired temperature. The vacuum pump is switched on (6) and the pressure is reduced until the vapour-pressure-of-water at a selected temperature is reached. When the water is boiling, the basket is taken down with the handle. At the end of the cooking time, the basket goes up and the pressure is restored by opening the vacuum valve (7). After that, the lid is opened and the product can be cooled to store refrigerated.

For sous-vide treatment, samples were placed avoiding the overlapping and they were vacuum-sealed (98\% vacuum) in heat-resistant polyethylene pouches (Cryovac ${ }^{\circledR}$ HT3050, Cryovac Sealed Air Corporation, Barcelone, Spain) using a vacuum packaging machine (EV-25, Technotrip, Spain) applying a double sealing. The permeability characteristics of pouches were: $10 \mathrm{~g} / 24 \mathrm{~h} \mathrm{~m}^{2}$ (ASTM $\mathrm{F}$ 1249) for the moisture vapor transmission rate (MVTR); $10 \mathrm{~cm}^{3} / \mathrm{m}^{2} 24 \mathrm{~h}$ (ASTM D3985) for $\mathrm{O}_{2}$ transmission rate at $23^{\circ} \mathrm{C}$ and $0 \% \mathrm{RH} ; 19$ $\mathrm{cm}^{3} / \mathrm{m}^{2} 24 \mathrm{~h}$ (ASTM D3985) for $\mathrm{O}_{2}$ transmission rate at $23{ }^{\circ} \mathrm{C}$ and $80 \% \mathrm{RH} ; 35 \mathrm{~cm}^{3} / \mathrm{m}^{2} 24 \mathrm{~h}$ (ASTM D1434) for $\mathrm{CO}_{2}$ transmission rate at $23{ }^{\circ} \mathrm{C}$ and $0 \% \mathrm{RH}$. The cooking treatment was performed with the previously mentioned device with the traditional lid for atmospheric cooking.

After cooking with traditional cooking and cook-vide treatments, samples were vacuum-sealed (98\% vacuum) in heat-resistant polyethylene pouches (Cryovac ${ }^{\circledR} \mathrm{HT} 3050$, Cryovac Sealed Air Corporation, Barcelone, Spain) using a vacuum packaging machine (EV-25, Technotrip, Spain).

All samples were stored at $3-4{ }^{\circ} \mathrm{C}$ for $24 \mathrm{~h}$ before the instrumental measurements to simulate the conditions in the catering industry that applies the sous-vide to minimize the workload during services.

\subsection{EXPERIMENTAL DESIGN}

For traditional cooking, temperature applied was $100{ }^{\circ} \mathrm{C}$ and cooking times are shown in Table 2 . The cooking times were different for sous-vide and cook-vide compared to traditional cooking in order to achieve two criteria. The first one is to have one cooking time in common with traditional cooking to allow 
a comparison; and the second one is that the cooked vegetables should be well-done but firm to the bite; a sensorial test (data not showed) was applied to define the rest of cooking times.

For sous-vide and cook-vide the temperature applied was $80{ }^{\circ} \mathrm{C}$ and $90{ }^{\circ} \mathrm{C}$. In the case of vegetables, the temperature of the work is recommended to be above $80{ }^{\circ} \mathrm{C}$ to assure gelatinization of the starch, softening of fibres and pectins (Sila and others 2009), and inactivation of enzymes; and below $100{ }^{\circ} \mathrm{C}$ to avoid ballooning of the pouch applying sous-vide. De Baerdemaeker and Nicolaï (1995) explained the phenomenon of ballooning based on the difference between inner and external pressure of the pouch. The way to increase the pressure of the water vapour and air inside the pouch according to the temperature are different. The air pressure increases linearly with the temperature according to the ideal gas law; while the water vapour pressure increases exponentially following the Clausius-Clapeyron equation. Therefore, the pressure becomes equal to atmospheric pressure at $90{ }^{\circ} \mathrm{C}$. Above that packaging pressure, ballooning may occur since the internal pressure becomes greater than the external pressure, which is probably around $100^{\circ} \mathrm{C}$.

For cook-vide is necessary to reduce the water vapour pressure under the atmospheric pressure, for this reason the cooking temperature is less than $100{ }^{\circ} \mathrm{C}$. To facilitate the comparison between sous-vide and cook-vide, the studied temperatures were $80{ }^{\circ} \mathrm{C}$ and $90{ }^{\circ} \mathrm{C}$ and each one was related to a specific time (Table 2). According to the temperature, pressure inside the device varied from 47.3 to $69.7 \mathrm{kPa}$ (absolute pressure) because a vacuum pump low the pressure until the vapour pressure of water of the heating media is reached during the cook-vide.

\subsection{INSTRUMENTAL TEXTURE ANALYSIS}

The firmness of samples was measured at room temperature $\left(25^{\circ} \mathrm{C}\right)$ by a puncture test using a Texture Analyser TA-XT2 (Texture Technologies Corp., Scarsdale, NY, USA) according with the methodology followed by Garcia-Segovia and others (2008) in potatoes, Iborra-Bernad and others (2013a) in green beans and Iborra-Bernad and others (2013b) in carrots.

In potatoes and carrots cylinders, the firmness test was conducted with a $2 \mathrm{~mm}$-diameter stainless-steel flat-head probe (TA P/2). The probe completely penetrated perpendicular into the surface of the 
194

195

196

197

198

199

200

201

202

203

204

205

206

207

208

209

210

211

212

213

214

215

cylinders. The penetration speed was $1 \mathrm{~mm} \cdot \mathrm{s}^{-1}$, and post-speed was $10 \mathrm{~mm} \cdot \mathrm{s}^{-1}$. Firmness was considered as the maximum-recorded force during the puncture test. In carrots, one measurement for each tissue, xylem and phloem, was carried out for each cylinder. In potatoes just one measurement was conducted in each cylinder. Six cylinders were analyzed for each treatment.

In green beans the texturometer was equipped with a $2 \mathrm{~mm}$ diameter stainless-steel needle probe (TA $\mathrm{P} / 2 \mathrm{~N}$ ) and measurements were taken perpendicular to the surface of the pods and seeds were avoided. Three measurements were carried out for each pod and six pods were analyzed for each treatment. The vertical displacement of the needle probe was held constant in order to ensure the full penetration all along the thickness of the pod. The speed of penetration was $2 \mathrm{~mm} \cdot \mathrm{s}^{-1}$, and pre- and post-speeds were both $5 \mathrm{~mm} \cdot \mathrm{s}^{-1}$.

Data were collected and analyzed using Texture Exponent software (Stable MicroSystems, Godalming, England).

\subsection{COLOR MEASUREMENT}

Color was recorded using a Minolta CM3600d colorimeter (Minolta Corp., Ramsey, NY, USA). The instrument was calibrated with a ceramic reference, illuminant $C$, prior to use. CIE-L*a*b* coordinates were obtained using D65 illuminant and $10^{\circ}$ observer as reference system. Registered parameters were $\mathrm{L}^{*}$ (brightness: $\mathrm{L}^{*}=0$ [black], $\mathrm{L}^{*}=100[$ white $\left.]\right), \mathrm{a}^{*}\left(-\mathrm{a}^{*}=\right.$ greenness, $+\mathrm{a}^{*}=$ redness $), \mathrm{b}^{*}\left(-\mathrm{b}^{*}=\right.$ blueness, $+\mathrm{b}^{*}$ $=$ yellowness) and total color differences ( $\Delta \mathrm{E}^{*} \mathrm{ab}$ ) were calculated following the equation (Eq. 1):

$$
\Delta E^{*} a b=\sqrt{\Delta L^{* 2}+\Delta a^{*^{2}}+\Delta b^{* 2}}
$$

In potatoes and carrots, the surface color in the top and in the bottom of each cylinder was measured in ten samples per treatment. For each treatment in green beans, ten samples of green beans were used to measure the skin color and the measure was repeated two times on each individual pod. 


\subsection{DETERMINATION OF ANTIOXIDANTS}

217

\subsubsection{DETERMINATION OF TOTAL MONOMERIC ANTHOCYANINS}

The determination of total monomeric anthocyanins was based on the $\mathrm{pH}$ differential method (Lee and others 2005). For the test, potatoes were removed from the pouches, they were placed on a paper for 1 min, and then the samples were slightly dried with a paper. For sample preparation $40 \mathrm{~g}$ of cooked potato were chopped. After, $2 \mathrm{~g}$ of the chopped product was homogenized for 30 seconds with $20 \mathrm{~mL}$ of methanol (Panreac, Barcelona, Spain) and $0.1 \mathrm{~mL}$ of hydrochloride acid $(37 \% \mathrm{HCl}$, Panreac, Barcelona, Spain). The homogenate was stored during $24 \mathrm{~h}$ at $4{ }^{\circ} \mathrm{C}$ in dark conditions, and after, it was centrifuged (10.000 rpm, $10 \mathrm{~min}, 4^{\circ} \mathrm{C}$ ) to obtain a supernatant. Aliquots of $0.4 \mathrm{~mL}$ were added to $3.6 \mathrm{~mL}$ of $\mathrm{pH} 1.0$ buffer and pH 4.5 buffer, prepared as suggested by Lee (2005). After waiting between $20 \mathrm{~min}$ and $50 \mathrm{~min}$, samples were evaluated at $\lambda=700$ and $530 \mathrm{~nm}$ in a spectrometer (Helios Zeta UV-VIS, Thermo Fisher Scientific, UK). The anthocyanin pigment concentration was expressed as cyanidin-3-glucoside equivalents per $100 \mathrm{~g}$ of cooked samples (molecular weight $=449.2 \mathrm{~g} / \mathrm{mol}$ for cyanidin-3-glucoside (cyd-3glu); $\varepsilon=26900$ molar extinction coefficient, in $\mathrm{L} \mathrm{mol}^{-1} \mathrm{~cm}^{-1}$ ). Four repetitions were done for each cooking treatment.

\subsubsection{DETERMINATION OF ASCORBIC ACID}

Ascorbic acid content was determined with a Titrino 702 SM (Metrohm, Ltd., Herisau, Switzerland) by bivoltammetric method using a Metrohm 6.0308.100 (Switzerland) double platinum electrode following the Metrohm method 42-J2 (Manual Methohm of analysis of Fruits and vegetables, Metrohm, Ltd., Herisau, Switzerland).The method is based on the oxidation of ascorbic acid to dehydroascorbic acid through the use of iodine. The results are independent of inherent coloration of the sample due to the bivoltametric indication.

For the test, green beans were removed from the pouches, they were placed on a paper for $1 \mathrm{~min}$, and then the samples were slightly dried with a paper. Then, samples were liquefied, after $20 \mathrm{~mL}$ of the liquefied were placed into the titration beaker with $30 \mathrm{~mL}$ of oxalic acid solution $(1 \mathrm{~g} / \mathrm{L}$, Panreac, Barcelona, Spain), treated with $2 \mathrm{~mL}$ glyoxal solution (40\%, Panreac, Barcelona, Spain), briefly stirred and stood settle for $5 \mathrm{~min}$. After the addition of $5 \mathrm{~mL}$ sulfuric acid ( $25 \% \mathrm{v} / \mathrm{v}$, Panreac, Barcelona, Spain), it was 
242

243

244

245

titrated with iodine (0.01 M, Panreac, Barcelona, Spain) up to the endpoint, which was considered the greatest loss of $\mathrm{mV}$.

The concentration was expressed as g of ascorbic acid per $100 \mathrm{~g}$ of product. Four repetitions were done for each cooking treatment.

\subsubsection{DETERMINATION OF $\beta$-CAROTENE}

The methodology of Olives and others (2006) was used to extract the carotenoids present in carrots. For the test, carrots were removed from the pouches, they were placed on a paper for 1 min, and then the samples were slightly dried with a paper. After, $5 \mathrm{~g}$ of sample were placed in a beaker, protecting them from light, and then they were mixed with $100 \mathrm{~mL}$ of acetone/ethanol/hexane (25:25:50, v/v/v) extraction solvent and magnetically stirred for $30 \mathrm{~min}$. Then, $15 \mathrm{~mL}$ of distilled water were added and an upper aliquot layer of $0.6 \mathrm{~mL}$ was dried under a stream of liquid nitrogen. The residue was dissolved with a methanol/tetrahydrofuran/acetonitrile solution $(55: 15: 30, \mathrm{v} / \mathrm{v} / \mathrm{v})$ to a final volume of $4 \mathrm{~mL}$. The spectrophotometric reference method of AOAC (2000) was used for quantification. Sample absorbance was measured at $446 \mathrm{~nm}$ (Helios Zeta UV-VIS, Thermo Fisher Scientific, UK). The total carotenoid content was expressed in $\mathrm{mg}$ of $\beta$-carotene per $100 \mathrm{~g}$ of cooked carrots. Standard $\beta$-carotene was provided by Fluka-Biochemika (USA). Three repetitions were conducted per each cooking treatment.

\subsection{MICROSTRUCTURE OF CELL WALL IN THE COOKED VEGETABLES}

The sample microstructure was observed with a secondary electrons image using cryo-scanning electron microscopy (cryo-SEM) with a JEOL JSM-5410 microscope (Jeol, Tokyo, Japan). A cryo-workstation Gatan was used in this work. Samples were cut into rectangular pieces $4 \times 1.5 \times 5 \mathrm{~mm}$. The samples, previously frozen by immersion in slush nitrogen $\left(-210^{\circ} \mathrm{C}\right)$, fractured, etched and gold coated, were viewed in the cryo-SEM. The sublimation conditions were: $5 \mathrm{kV}$, at $-90^{\circ} \mathrm{C}, 10^{-5}$ Torr vacuum, for $15 \mathrm{~min}$. The observation conditions were $15 \mathrm{kV}$ at $10 \mathrm{~mm}$ wd (working distance) and the liquid nitrogen temperature was $-190{ }^{\circ} \mathrm{C}$. Using this technique, the fractured surface of the frozen sample was viewed directly at $-150{ }^{\circ} \mathrm{C}$ or lower. Micrographs of the preparation of purple-flesh potato, green bean pods and carrots were analyzed after a day of storage at $4{ }^{\circ} \mathrm{C}$. The micrographs were taken at 750 magnifications to observe changes in the cell 
walls. Samples observed were raw ones, others cooked with traditional treatment $\left(100^{\circ} \mathrm{C}\right)$ and using sousvide and cook-vide.

\subsection{DATA ANALYSIS}

Variability in texture parameter, color coordinates and antioxidant content among conditions were analyzed with one-way ANOVA. All ANOVA were followed by a LSD posthoc test to find out significant differences ( $p \leq 0.05)$. The software employed was Statgraphics Centurion (STSC, Rockville, MD).

\section{RESULTS AND DISCUSSION}

\subsection{EFFECTS OF COOKING TREATMENTS ON FIRMNESS}

Firmness that consumers like for each vegetable was taken as target to compare different cooking methods. Fig. 2a shows the results of firmness of purple-flesh potato cooked with traditional cooking, cook-vide and sous-vide. Firmness was 12.5 (1.7) N (standard deviation showed in brackets) in raw samples and ranged from $4.25(0.98) \mathrm{N}$ to $0.53(0.06) \mathrm{N}$ in cooked ones considering all cooking treatments. No significant differences were found in firmness between samples cooked for 25 min with traditional cooking and with the other treatments (cook-vide and sous-vide) at $90{ }^{\circ} \mathrm{C}$. This means that a constant level in firmness was reached during cooking as observed previously by Tijskens and Schijvens (1987). However, cook-vide and sous-vide treatments applied at $80{ }^{\circ} \mathrm{C}$ provided firmer samples $(p \leq 0.05)$ than traditional cooked ones. The $\beta$-elimination reaction in pectic substances, main components of the lamella media, increases substantially starting at $80{ }^{\circ} \mathrm{C}$ (Sila and others 2009). This observation explain that samples cooked (cook-vide and sous-vide) at $80{ }^{\circ} \mathrm{C}$ were firmer than ones cooked at $90{ }^{\circ} \mathrm{C}$ with the same cooking time.

Concerning green beans (Fig. 2b), raw samples had a firmness of $5.9(0.6) \mathrm{N}$, while cooked samples displayed firmness between $0.64(0.09) \mathrm{N}$ and $2.66(0.16) \mathrm{N}$. Comparing traditional cooking, cook-vide at $90{ }^{\circ} \mathrm{C}$ and sous-vide at $90{ }^{\circ} \mathrm{C}$, differences were found between firmness of samples cooked for 20 min ( $p \leq 0.05)$. Traditional cooking $\left(100^{\circ} \mathrm{C}\right)$ provided the softer samples, the sous-vide at $90^{\circ} \mathrm{C}$ maintained more of the firmness and the samples cooked with cook-vide had an intermediate degree of firmness. To 
293

294

295

296

297

298

299

300

301

302

303

304

305

306

307

308

309

310

311

312

provide similar firmness ( $p>0.05)$ applying sous-vide and cook-vide with the same temperature $\left(80^{\circ} \mathrm{C}\right.$ or $\left.90{ }^{\circ} \mathrm{C}\right) 20$ min more of cooking time were required in sous-vide treatment. The contact with the external water in traditionally and cook-vide cooked samples could increase the hydration of the secondary and primary walls, which characterize its hypodermis cells (Sterling and Shimazu 1961). The solubilisation of branched regions (rhamnogalacturonan) of the cell wall could increase, reducing the resistance to external strength, and then, the firmness (Stolle-Smits and others 1995)(Fig. 2b). This difference between heat treatments could be the origin of the differences detected in the puncture test.

Regarding carrots (Fig. 2c and Fig. 2d), the firmness of phloem (external) and xylem (internal) tissues were studied. The firmness values measured in raw samples were $10.6(0.9) \mathrm{N}$ in phloem tissue and $12.2(0.5) \mathrm{N}$ in xylem tissue. In phloem tissue, samples cooked with sous-vide and cook-vide at $80^{\circ} \mathrm{C}$ were firmer than samples cooked with shorter treatments at higher temperature $\left(100{ }^{\circ} \mathrm{C}\right.$-traditional cooking- and $90^{\circ} \mathrm{C}-$ cook-vide and sous-vide-). As observed by Iborra-Bernad and others (2013b) the effect of temperature in the softening process is greater than the cooking time. In xylem tissues, sous-vide samples cooked at $80^{\circ} \mathrm{C}$ were also the firmest ones. Similar firmness of cooked samples (sous-vide and cook-vide) $(p>0.05)$ at this temperature $\left(80^{\circ} \mathrm{C}\right)$ was achieved after cooking with sous-vide for $70 \mathrm{~min}$ and with cook-vide for $40 \mathrm{~min}$. Traditional cooked samples were the softer samples probably due to its high temperature which could increase the degradation of pectic substances (Van Buggenhout and others 2009). Comparing samples cooked with sous-vide and cook-vide at $90{ }^{\circ} \mathrm{C}$, it was found that sous-vide kept samples firmer than cookvide treatment in both tissues (phloem and xylem). Loss of firmness was associated with substantial dissolution, depolymerization, and, apparently, destruction of cell wall pectins in carrots (Greve and others 1994). Therefore, as commented with respect to green beans, external water available in the cookvide treatment may have the effect of increasing the dissolution of pectic material as compared to the sous-vide treatment. In addition, the heat transfer coefficient of surfaces is higher in boiling water (cookvide) than in liquid water (sous-vide).

The obtained results highlight the different effect of each treatment according to the different compositions and histology of the vegetables. 
319

320

321

322

323

324

325

326

327

328

329

330

331

332

333

334

335

336

337

338

339

340

341

342

343

\subsection{EFFECT OF COOKING TREATMENT ON COLOR}

Fig. 3a shows total color difference ( $\left.\Delta \mathrm{E}^{*} \mathrm{ab}\right)$ of cooked purple-flesh potato, the lower values were observed applying sous-vide at $80{ }^{\circ} \mathrm{C}$ and $90{ }^{\circ} \mathrm{C}(\mathrm{p} \leq 0.05)$, meaning that the color of products is more similar to the raw samples. Larger $\Delta \mathrm{E}^{*}$ ab values were observed in treatments where samples were in contact with boiling water (traditional cooking, cook-vide at $80^{\circ} \mathrm{C}$ and $90^{\circ} \mathrm{C}$ ). Differences in $\Delta \mathrm{E}^{*}$ ab between treatments could be explained by the leakage of anthocyanins (hydrophilic and choromophore compounds) in cooking water using cook-vide and traditional cooking, while sous-vide treatment isolated the product from the external cooking media.

Concerning green bean pods, raw samples were greener $\left(-\mathrm{a}^{*}=-8.7(0.5)\right)$ than cooked ones (from $-1.5(1.0)$ to $-5.0(0.4))$. These differences could be related with chlorophyll degradation, which converts the bright green color to olive-color (Van Boekel 1999). Total color difference ( $\Delta \mathrm{E}^{*}$ ab) (Fig. 3b) in samples cooked with traditional cooking ranged from 12 to 14 , similar to the majority of the other cooked samples ( $p>0.05)$. It was observed a difference between cook-vide and sous-vide samples at $80{ }^{\circ} \mathrm{C}$, mainly related to coordinate $a^{*}$ as observed in previous studies (Iborra-Bernad and others 2013a). The isolation of samples inside a pouch in sous-vide could retain the organic acids, which probably increased the degradation of the chlorophyll by a slight decrease of $\mathrm{pH}$ (Koca and others 2006).

In carrots (Fig. 3c), total color difference ( $\triangle \mathrm{E}^{*} \mathrm{ab}$ ) ranged from $12.2(1.2)$ to 17 (3). The lowest differences belonged to samples cooked with traditional cooking for $10 \mathrm{~min}$, the shortest cooking time. This treatment had lower values $(p \leq 0.05)$ than sous-vide at $90^{\circ} \mathrm{C}$ and cook-vide at $80^{\circ} \mathrm{C}$ for all cooking times. Higher temperatures maybe destabilize a little more the homeostasis of cells, facilitating the destruction of carotenoid-protein-complexes increasing the $\beta$-carotene extraction (Ryan and others 2008; Van het Hof and others 2000). However, this possible modification does not affect significantly the global color of the cooked carrots.

As observed in the previous section about firmness, color has been affected in different ways according to the cooking treatment and the nature of the main chromophore in each vegetable. In this sense, the 
344

345

purple-flesh potato seemed to be more affected by the cooking treatment due to the hydrophilic nature of the anthocyanins (easily leached).

\subsection{EFFECT OF COOKING TREATMENTS ON ANTHOCYANINS, ASCORBIC ACID} AND $\beta$-CAROTENE

In purple-flesh potato, the anthocyanin content of raw samples was around 49 (10) cyanidin-3-glucoside equivalents/100 g of cooked products (Fig. 4a). In cooked samples contents ranged between 22.3 (13) to 52.7 (8) cyanidin-3-glucoside equivalents/100 g of cooked products. Traditional cooking, sous-vide at $80{ }^{\circ} \mathrm{C}$ and cook-vide at $80^{\circ} \mathrm{C}$ for 25 min treatments showed lower anthocyanin values compared to raw samples $(p \leq 0.05)$. Traditional cooked samples had the lowest anthocyanin content probably due to the leakage into the cooking water as a main effect, and a higher cooking temperature $\left(100{ }^{\circ} \mathrm{C}\right)$ could destroy part of the anthocyanins content as a second effect. However, their firmness are similar to potatoes cooked 25 min at $90{ }^{\circ} \mathrm{C}$ in sous-vide and cook-vide (Fig.1), highlighting the importance of the cooking treatment. In cook-vide treatments, no differences were found between treatments at $80{ }^{\circ} \mathrm{C}$ and $90{ }^{\circ} \mathrm{C}$, while the extraction of the anthocyanins of samples cooked with sous-vide at $90{ }^{\circ} \mathrm{C}$ were higher than the one carried out in sous-vide samples at $80^{\circ} \mathrm{C}$ after 30 min cooking. Longer cooking times could increase the extraction of the anthocyanins from the potato matrix by higher destruction of their cell walls (Van Boekel and others 2010). However, a higher diffusion of anthocyanins into the aqueous media in cook-vide treatments could decrease the measured content, while the anthocyanin of the sous-vide samples could be retained in the pouches (avoiding the contact with the cooking media). In other studies with purple onions and red cabbage, lower losses of anthocyanin were also described in cooking treatments without cooking media contact (Rodrigues and others 2009; Volden and others 2008). Further studies are required to understand how these cooking treatments could affect the bioaccessibility and bioavailability of anthocyanins in potatoes. Other studies in fruits and vegetables observe a low anthocyanin bioaccessibility. In the case of raw figs, the bioaccessibility was quite low (0-5\% of the initial values) in cyanidin-3-glucoside, whereas for dried figs, anthocyanins were not observed (Kamiloglu and Capanoglu 2013). Studies conducted in mulberry noticed that the bioaccessibility of anthocyanins were less than $5 \%$ after the intestinal digestion. 
370

371

372

373

374

375

376

377

378

379

380

381

382

383

384

385

386

387

388

However, it seems that phenolics are generated from degradation of anthocyanins under intestinal environment which explain the radical scavenging ability during the digest (Liang and others 2012). Therefore, Bermúdez-Soto and others (2007) concluded that the study of bioaccessibility, bioavailability and biological activity in dietary polyphenols are complex because they are transformed in the small intestine into other unknown and/or undetected structural forms with different chemical properties due to their highly sensitive to the mild alkaline conditions. Moreover, Yang and others (2011) suggests that the bioavailability of anthocyanins varies markedly depending on food matrices, considering other antioxidants and macronutrients in the same meal.

Fig. $4 \mathrm{~b}$ shows the ascorbic acid content in green beans. The ascorbic acid content in raw green beans was 14.6 (1.0) $\mathrm{mg}$ of ascorbic acid/100 g of cooked product. The ascorbic acid content in cooked samples ranged from 13.7 (0.7) to 18 (2) $\mathrm{mg}$ of ascorbic acid/100 g of cooked product. Samples cooked with shorter treatments of sous-vide at $80^{\circ} \mathrm{C}$ (40 and $50 \mathrm{~min}$ ), cook-vide at $80^{\circ} \mathrm{C}(40 \mathrm{~min})$ and cook-vide at 90 ${ }^{\circ} \mathrm{C}$ (20 and $\left.30 \mathrm{~min}\right)$ had higher ascorbic contents $(p \leq 0.05)$ than raw samples. This increase of the ascorbic content could be explained by a reduction of moisture in cooked samples due to the damage in cells for heating (see next section). A reduction in moisture increases the current proportion of ascorbic content despite losses of this thermosensitive molecule by heating effect (Barrett and Lloyd 2012).

In the case of carrots (Fig. 4c), $\beta$-carotene was selected as nutritional indicator because this compound is chemically hydrophobic and sensitive to temperature and oxygen. $\beta$-carotene content in raw samples was 11 (2) $\mathrm{mg}$ of $\beta$-carotene/100 g of cooked product. This content was similar to the measured in sous-vide samples ( $p>0.05$ ) at $80{ }^{\circ} \mathrm{C}$ and $90{ }^{\circ} \mathrm{C}$. Treatments in contact with boiling water (cook-vide at $80{ }^{\circ} \mathrm{C}$ and 90 ${ }^{\circ} \mathrm{C}$, traditional cooking at $\left.100{ }^{\circ} \mathrm{C}\right)$ resulted in higher $\beta$-carotene content than raw samples $(\mathrm{p} \leq 0.05)$ probably due to a larger denaturation of carotenoproteins and a higher solubilisation of pectic substances of the cell wall, leading these cooked samples to a better extractability and higher concentrations determined. This better extractability has been related with a higher bioaccessibility (Failla and others 2008; Hornero-Méndez and Mínguez-Mosquera, 2007). Lemmens and others (2009) observed that modification in texture and the $\beta$-carotene in vitro bio-accessibility are inversely correlated, contrary to 
our studies where carrots with similar texture are releasing in different amount of carotenes according to the cooking treatment. In this regard, the bioaccessibility could also be different. Therefore, Aherne and others (2010) noticed cooking not only enhances the bioaccessibility and bioavailability of all-trans $\beta$ carotenes but also its cis forms. Their study suggests food matrix and degree of processing play important roles on carotenoid isomerisation and $\beta$-carotene isomer bioavailability. Micrographs (Fig. 5) suggest a different damage in the carrots cells, which could explain the different releasing level of carotenoids.

As a conclusion, it has been observed that sous-vide treatment preserved better anthocyanins and higher levels of $\beta$-carotene were extracted in carrots boiled directly in contact with water (cook-vide and traditional cooking).

\subsection{MICROSTRUCTURE OF COOKED VEGETABLES.}

Fig. 5a shows potato micrographs of raw and cooked samples: traditional cooking $\left(100{ }^{\circ} \mathrm{C}-15 \mathrm{~min}\right)$, cookvide $\left(90{ }^{\circ} \mathrm{C}-30 \mathrm{~min}\right)$ and sous-vide $\left(90{ }^{\circ} \mathrm{C}-30 \mathrm{~min}\right)$. Raw cells showed cytoplasm organelles (the majority containing starch granules) and lines (equivalent to the solute content) which were crystallized out in a pure form after water sublimation process required during cryo-SEM preparation. Unlike raw samples with lines of solutes in the cytoplasm, the starch gelatinized by high temperature completely filled the lumen of the cytoplasm. During the gelatinization of starch, the molecule is hydrated with the available water, creating the swelling pressure described by Jarvis (1992). In treatments with boiling water (traditional cooking and cook-vide), the water media could diffuse through the damaged membranes and swells the starch causing higher swelling pressure than sous-vide ones, which have only access to available water from the internal water cells. Comparing sous-vide and cook-vide, starch gelatinized in cook-vide samples was visually more homogeneous (probably due to a larger hydration) than that gelatinized in sous-vide ones. Swelling pressure avoided the wrinkle of the cell wall observed in the micrographs of the sous-vide cells. No differences were described in the firmness between those treatments (Fig. 2a), probably because the gelatinization has a slight effect in the firmness loss as suggested by Verlinden (1995). Therefore, Iborra-Bernad and others (2014b) observed that adhesiveness and cohesiveness was higher in purple-flesh 
potato cooked with sous-vide compared to ones cooked with sous-vide, while firmness was similar between samples cooked at the same temperature and cooking time.

Fig. $5 \mathrm{~b}$ shows green beans micrographs of raw and cooked samples: traditional cooking $\left(100{ }^{\circ} \mathrm{C}-10 \mathrm{~min}\right)$, cook-vide $\left(90{ }^{\circ} \mathrm{C}-20 \mathrm{~min}\right)$ and sous-vide $\left(90{ }^{\circ} \mathrm{C}-20 \mathrm{~min}\right)$. In green beans, epidermal and hypodermal layer cells were observed (Fig. 5b). As described by Reeve and Brown (1968), secondary walls were found in the hypodermal tissue of the bean pods. In raw samples, lines drawn in cytoplasmic regions (equivalent of the solute content) were more than in cooked ones. Moreover, traditional cooked cells ( $\left.100{ }^{\circ} \mathrm{C}-10 \mathrm{~min}\right) \mathrm{had}$ fewer lines than cells of samples cooked by cook-vide or sous-vide. A higher temperature applied could destabilize more intensely the cell homeostasis, which facilities the increment of the loss of the intracellular content. Moreover, traditional cooked samples seem more damaged in secondary walls because the walls reduced their thickness probably by the temperature applied $\left(100{ }^{\circ} \mathrm{C}\right)$ which could increase the solubilization and depolymerisation of pectic materials (Stolle-Smits 1995).

In carrot micrographs (Fig. 5c) phloem cells were examined in raw samples and cooked ones: traditional cooking (100 $\left.{ }^{\circ} \mathrm{C}-10 \mathrm{~min}\right)$, cook-vide $\left(90{ }^{\circ} \mathrm{C}-30 \mathrm{~min}\right)$ and sous-vide $\left(90{ }^{\circ} \mathrm{C}-30 \mathrm{~min}\right)$. Raw samples showed mainly cells and areas full of lines (related to the solute content). Traditional cooked samples were poorly filled compared with sous-vide and cook-vide samples pointing to more damaged membranes. Trejo-Araya and others (2009) observed less tissue damage which resulted in smaller gaps in sous-vide carrots and high pressure processing samples than in traditional cooked ones. The level of damaged cells seemed to be inversely related with carotene content, because sous-vide samples had lower content than traditional cooked and cook-vide samples (Fig. 4c). Furthermore, carotenoids are hydrophobic compounds present in carrot root as large carotenoid crystals in chromoplasts (Schweiggert and others 2012), where they are linked with proteins. Cooking treatment is able to break up the molecular linkages between carotenoids and proteins increasing the extractability in cooked samples (Van het Hof and others 2000). Nevertheless, sous-vide samples displayed some organelles which suggest a less aggressive treatment. It could explain that $\beta$-carotene values of sous-vide samples were similar those measured in raw samples (Fig. 4c). 
446

447

448

449

450

451

452

453

454

455

456

457

458

459

460

461

462

463

464

465

466

467

468

469

470

471

\section{CONCLUSIONS}

Changes in texture, color, nutritional indicators and structure provided by three different cooking treatments (traditional cooking, cook vide and sous vide) in different vegetables were studied.

Our study shows why the suitability of the cooking treatment is different according to the characteristics of nutritional compounds and the structural properties of each product. Purple-flesh potatoes should be cooked with treatments isolating from the cooking media, such as sous-vide, in order to reduce the anthocyanin leakage in the cooking media. In addition, we noticed a different swelling of the starch in potatoes cooked with different treatments despite similar firmness. The effect of temperature, the role of the cooking media contact with vegetables during cooking and the impact of the low pressure in the cells structures damages are the main factors which explain the different spreading of the starch in the cellular lumen. Further studies could elucidate the role of each one of the factors in the modification of textural and sensory properties in starchy vegetables. In the study with green beans it was noticed that the contact with cooking media seems to have an important effect in the firmness at the same temperature and time (cook-vide vs. sous-vide). The softening was higher when the cooking water was in contact with samples and it was dependent on the temperature. Studies focused in the influence of the cooking media contact and the pressure on the vegetable tissues should be conducted in order to model the relationship between both factors. Another important result observed is that $\beta$-carotenes are more available in traditional cooking (boiling water) and cook-vide compared to the sous-vide due to larger cell wall damages in carrots, despite a similar firmness. Studies about the bioavailability and the bioaccessibility of antioxidants could be recommended to better understand the impact of type of cooking in the nutrition and modify the guidelines of public health according to these conclusions. Our results highlight that individual studies of vegetables are required for comparing cooking treatments due to the complex structure and the main antioxidant compounds characterizing each vegetable.

\section{ACKNOWLEDGEMENTS}

Author Iborra-Bernad was supported by the Generalitat Valenciana under FPI (Researcher Formation Program) grant. Special thanks to the Electron Microscopy Service of the UPV. 
473

474

475

476

477

478

479

480

481

482

483

484

485

486

487

488

489

490

491

492

493

494

495

496

497

498

499

500

501

502

503

504

\section{Author Contributions}

C. Iborra collected test data, interpreted results and drafted the manuscript J. Martinez designed the study and interpreted results. P. Garcia prepared the samples to microstructure observation and interpreted the microstructure data.

\section{REFERENCES}

AOAC. (2000). Official methods of analysis (Vol. 17th ed.). Gaithersburg: AOAC.

Aherne, S. A., Daly, T., Jiwan, M. A., O'Sullivan, L., \& O'Brien, N. M. (2010). Bioavailability of $\beta$-carotene isomers from raw and cooked carrots using an in vitro digestion model coupled with a human intestinal Caco-2 cell model. Food Research International, 43(5), 1449-1454.

Baldwin, D. E. (2012). Sous vide cooking: A review. International Journal of Gastronomy and Food Science, $1(1), 15-30$.

Barrett, D. M., \& Lloyd, B. (2012). Advanced preservation methods and nutrient retention in fruits and vegetables. Journal of the Science of Food and Agriculture, 92, 7-22.

Bermúdez-Soto, M.-J., Tomás-Barberán, F.-A., \& García-Conesa, M.-T. (2007). Stability of polyphenols in chokeberry (Aronia melanocarpa) subjected to in vitro gastric and pancreatic digestion. Food Chemistry, 102(3), 865-874.

Chiavaro, E., Barbanti, D., Vittadini, E., \& Massini, R. (2006). The effect of different cooking methods on the instrumental quality of potatoes (cv. Agata). Journal of Food Engineering, 77(1), 169-178.

Failla, M. L., Huo, T., \& Thakkar, S. K. (2008). In vitro screening of relative bioaccessibility of carotenoids from foods. Asia Pac. J. Clin. Nutr, 17(S1), 200-203.

García-Segovia, P., Andrés-Bello, A., \& Martínez-Monzó, J. (2007). Effect of cooking method on mechanical properties, color and structure of beef muscle (M. pectoralis). Journal of Food Engineering, 80(3), 813-821.

García-Segovia, P., Andrés-Bello, A., \& Martínez-Monzó, J. (2008). Textural properties of potatoes (Solanum tuberosum L., cv. Monalisa) as affected by different cooking processes. Journal of Food Engineering, 88(1), 28-35.

Greve, L. C., McArdle, R. N., Gohlke, J. R., \& Labavitch, J. M. (1994). Impact of heating on carrot firmness: changes in cell wall components. Journal of Agricultural and Food Chemistry, 42(12), 2900-2906.

Hornero-Méndez, D., \& Mínguez-Mosquera, M. I. (2007). Bioaccessibility of carotenes from carrots: Effect of cooking and addition of oil. Innovative Food Science \& Emerging Technologies, 8(3), 407-412.

Hui, Y. H., Ghazala, S., Graham, D. M., Murrell, K. D., \& Nip, W. K. (2003). Handbook of Vegetable Preservation and Processing. USA: Marcel Dekker, Inc. 
505

506

507

508

509

510

511

512

513

514

515

516

517

518

519

520

521

522

523

524

525

526

527

528

529

530

531

532

533

534

535

536

537

538

539

540

541

542

543

544

Iborra-Bernad, C., García-Segovia, P., \& Martínez-Monzó, J. (2014a). Effect of vacuum cooking treatment on physicochemical and structural characteristics of purple-flesh potato. International Journal of Food Science \& Technology, 49(4), 943-951.

Iborra-Bernad, C., Philippon, D., García-Segovia, P., \& Martínez-Monzó, J. (2013a). Optimizing the texture and color of sous-vide and cook-vide green bean pods. LWT - Food Science and Technology, 51(2), 507-513.

Iborra-Bernad, C., Tárrega, a., García-Segovia, P., \& Martínez-Monzó, J. (2013b). Comparison of Vacuum Treatments and Traditional Cooking Using Instrumental and Sensory Analysis. Food Analytical Methods, 7(2), 400-408.

Iborra-Bernad, C., Tárrega, a., García-Segovia, P., \& Martínez-Monzó, J. (2014b). Advantages of sous-vide cooked red cabbage: Structural, nutritional and sensory aspects. LWT - Food Science and Technology, $56(2), 451-460$.

Jarvis, M. C., Mackenzie, E., \& Duncan, H. J. (1992). The textural analysis of cooked potato. 2. Swelling pressure of starch during gelatinisation. Potato Research, 35(1), 93-102.

Kamiloglu, S., \& Capanoglu, E. (2013). Investigating the in vitro bioaccessibility of polyphenols in fresh and sun-dried figs (Ficus carica L.). International Journal of Food Science \& Technology, 48(12), 26212629.

Koca, N., Karadeniz, F., \& Burdurlu, H. S. (2006). Effect of pH on chlorophyll degradation and colour loss in blanched green peas. Food Chemistry, 100(2), 609-615.

Lachman, J., Hamouz, K., Musilová, J., Hejtmánková, K., Kotíková, Z., Pazderů, K., Cimr, J. (2013). Effect of peeling and three cooking methods on the content of selected phytochemicals in potato tubers with various colour of flesh. Food Chemistry, 138(2-3), 1189-1197.

Lee, J., Durst, R. W., \& Wrolstad, R. E. (2005). Determination of total monomeric anthocyanin pigment content of fruit juices, beverages, natural colorants, and wines by the $\mathrm{pH}$ differential method: Collaborative study. Journal of the Association of Official Analytical Chemists International, 88(5), 1269-1278.

Lemmens, L., Van Buggenhout, S., Oey, I., Van Loey, A., \& Hendrickx, M. (2009). Towards a better understanding of the relationship between the $\beta$-carotene in vitro bio-accessibility and pectin structural changes: A case study on carrots. Food Research International, 42(9), 1323-1330.

Leskova, E. (2006). Vitamin losses: retention during heat treatment and continual changes expressed by mathematical models. Journal of Food Composition and Analysis, 19(4), 252-276.

Liang, L., Wu, X., Zhao, T., Zhao, J., Li, F., Zou, Y., Yang, L. (2012). In vitro bioaccessibility and antioxidant activity of anthocyanins from mulberry (Morus atropurpurea Roxb.) following simulated gastrointestinal digestion. Food Research International, 46(1), 76-82.

Martínez-Hernández, G. B., Artés-Hernández, F., Colares-Souza, F., Gómez, P. A., García-Gómez, P., \& Artés, F. (2013). Innovative cooking techniques for improving the overall quality of a Kailan-hybrid broccoli. Food and Bioprocess Technology, 1, 0-1.

Olives Barba, A. I., Cámara Hurtado, M., Sánchez Mata, M. C., Fernández Ruiz, V., \& López Sáenz de Tejada, M. (2006). Application of a UV-vis detection-HPLC method for a rapid determination of lycopene and [beta]-carotene in vegetables. Food Chemistry, 95, 328-336. 
545

546

547

548

549

550

551

552

553

554

555

556

557

558

559

560

561

562

563

564

565

566

567

568

569

570

571

572

573

574

575

576

577

578

579

580

581

582

Reeve, R. M., \& Brown, M. S. (1968). Histological Development of the Green Bean Pod as Related to Culinary Texture. Journal of Food Science, 33(3), 321-326.

Rodrigues, A. S., Pérez-Gregorio, M. R., García-Falcón, M. S., \& Simal-Gándara, J. (2009). Effect of curing and cooking on flavonols and anthocyanins in traditional varieties of onion bulbs. Food Research International, 42(9), 1331-1336.

Ryan, L., O'Connell, O., O'Sullivan, L., Aherne, S. A., \& O'Brien, N. M. (2008). Micellarisation of carotenoids from raw and cooked vegetables. Plant Foods for Human Nutrition, 63(3), 127-133.

Schweiggert, R. M., Mezger, D., Schimpf, F., Steingass, C. B., \& Carle, R. (2012). Influence of chromoplast morphology on carotenoid bioaccessibility of carrot, mango, papaya, and tomato. Food Chemistry, 135(4), 2736-2742.

Sila, D. N., Van Buggenhout, S., Duvetter, T., Fraeye, I., De Roeck, A., Van Loey, A., \& Hendrickx, M. (2009). Pectins in processed fruits and vegetables: part II-structure-function relationships. Comprehensive Reviews in Food Science and Food Safety, 8(2), 86-104.

Sterling, C., \& Shimazu, F. (1961). Cellulose crystallinity and the reconstitution of dehydrated carrots. Journal of Food Science, 26(5), 479-484.

Stolle-Smits, T., Beekhuizen, J. G., van Dijk, C., Voragen, A. G. J., \& Recourt, K. (1995). Cell wall dissolution during industrial processing of green beans (Phaseolus vulgaris L.). Journal of Agricultural and Food Chemistry, 43(9), 2480-2486.

Szczesniak, A. S., \& Kahn, E. L. (1971). Consumer awareness of and attitudes to food texture I: Adults. Journal of Texture Studies, 2(2), 280-295.

Tijskens, L. M. M., \& Schijvens, E. E. H. M. (1987). Preservation criteria based on texture kinetics. In K. O. Paulus (Ed.), Influence of HTST Treatments on Product Quality and Nutritive Value of Food and Feed (pp. 84-102). Wageningen, The Netherlands.: Third Workshop COST 91 bis,.

Trejo-Araya, X. I., Smale, N., Zabaras, D., Winley, E., Forde, C., Stewart, C. M., \& Mawson, A. J. (2009). Sensory perception and quality attributes of high pressure processed carrots in comparison to raw, sous-vide and cooked carrots. Innovative Food Science \& Emerging Technologies, 10(4), 420-433.

Van Boekel, M. A. J. S. (1999). Testing of kinetic models: usefulness of the multiresponse approach as applied to chlorophyll degradation in foods. Food Research International, 32(4), 261-269.

Van Boekel, M., Fogliano, V., Pellegrini, N., Stanton, C., Scholz, G., Lalljie, S., ... Eisenbrand, G. (2010). A review on the beneficial aspects of food processing. Molecular Nutrition \& Food Research, 54(9), 1215-1247.

Van Buggenhout, S., Sila, D. N., Duvetter, T., Van Loey, A., \& Hendrickx, M. (2009). Pectins in processed fruits and vegetables: Part III-Texture engineering. Comprehensive Reviews in Food Science and Food Safety, 8(2), 105-117.

Van het Hof, K. H., West, C. E., Weststrate, J. A., \& Hautvast, J. G. (2000). Dietary factors that affect the bioavailability of carotenoids. The Journal of Nutrition, 130(3), 503-506.

Verlinden, B. E., Nicolaï, B. M., \& De Baerdemaeker, J. (1995). The starch gelatinization in potatoes during cooking in relation to the modelling of texture kinetics. Journal of Food Engineering, 24(2), 165-179. 
583

584

585

586

587

588

589
Volden, J., Borge, G. I. A., Bengtsson, G. B., Hansen, M., Thygesen, I. E., \& Wicklund, T. (2008). Effect of thermal treatment on glucosinolates and antioxidant-related parameters in red cabbage (Brassica oleracea L. ssp. capitata f. rubra). Food Chemistry, 109(3), 595-605.

Yang, M., I Koo, S., O Song, W., \& K Chun, O. (2011). Food matrix affecting anthocyanin bioavailability: review. Current Medicinal Chemistry, 18(2), 291-300. 
590

591

Table 1. Comparison of three cooking methods: sous-vide, cook-vide and traditional cooking.

\begin{tabular}{cccc}
\cline { 2 - 4 } & Sous-vide & Cook-vide & Traditional cooking \\
\hline $\begin{array}{c}\text { Temperature } \\
\begin{array}{c}\text { Reduction of the presence of } \\
\text { the oxygen }\end{array}\end{array}$ & Cooking temperature $<100^{\circ} \mathrm{C}$ & Cooking temperature $<100^{\circ} \mathrm{C}$ & Cooking temperature $\approx 100{ }^{\circ} \mathrm{C}$ \\
\hline $\begin{array}{c}\text { Material in contact with the } \\
\text { product }\end{array}$ & $\begin{array}{c}\text { Samples are inside of a vacuum } \\
\text { sealed pouch }\end{array}$ & $\begin{array}{c}\text { Contact of samples and } \\
\text { heating media }\end{array}$ & $\begin{array}{c}\text { Contact of samples and heating } \\
\text { atmedia }\end{array}$ \\
\hline Cooking media state & Liquid water without boiling & Boiling water & Boiling water \\
\hline
\end{tabular}

592

593

594 Table 2. Experimental design for purple-flesh potato, green bean pods and carrots.

\begin{tabular}{|c|c|c|ccc|}
\hline Treatment & Temperature & Vegetable & \multicolumn{3}{|c|}{ Cooking time (min) } \\
\hline \multirow{2}{*}{$\begin{array}{c}\text { Traditional } \\
\text { cooking }\end{array}$} & \multirow{2}{*}{$100{ }^{\circ} \mathrm{C}$} & Potatoes & 20 & 25 & 30 \\
\cline { 3 - 6 } & & Beans & 10 & 15 & 20 \\
\cline { 3 - 6 } & & Carrots & 10 & 20 & 30 \\
\hline
\end{tabular}

\begin{tabular}{|c|c|c|ccc|}
\hline \multirow{4}{*}{ Sous-vide } & \multirow{3}{*}{$80^{\circ} \mathrm{C}$} & Potatoes & 25 & 30 & 35 \\
\cline { 3 - 6 } & & Beans & 40 & 50 & 60 \\
\cline { 3 - 6 } & & Carrots & 40 & 55 & 70 \\
\cline { 3 - 6 } & \multirow{3}{*}{$90^{\circ} \mathrm{C}$} & Potatoes & 25 & 30 & 35 \\
\cline { 3 - 6 } & & Beans & 20 & 30 & 40 \\
\cline { 3 - 6 } & & Carrots & 30 & 45 & 60 \\
\hline
\end{tabular}

\begin{tabular}{|c|c|c|ccc|}
\hline \multirow{4}{*}{ Cook-vide } & \multirow{3}{*}{$80^{\circ} \mathrm{C}$} & Potatoes & 25 & 30 & 35 \\
\cline { 3 - 6 } & & Beans & 40 & 50 & 60 \\
\cline { 3 - 6 } & & Carrots & 40 & 55 & 70 \\
\cline { 3 - 6 } & \multirow{3}{*}{$90{ }^{\circ} \mathrm{C}$} & Potatoes & 25 & 30 & 35 \\
\cline { 3 - 6 } & & Beans & 20 & 30 & 40 \\
\cline { 3 - 6 } & & Carrots & 30 & 45 & 60 \\
\hline
\end{tabular}

595

596

597 
Fig. 1. Vacuum cooking system: (1) heating element and temperature probe, (2) pan, (3) lid, (4)

599 temperature selector, (5) manometer, (6) vacuum pump and (7) valve (source Iborra-Bernad and others 600 (2013)).

601

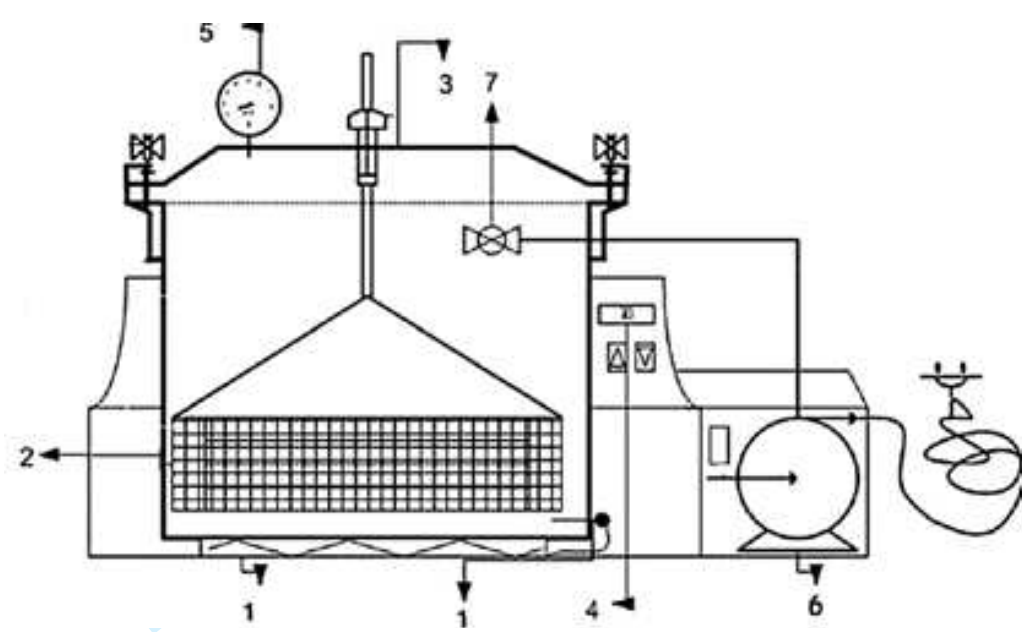


602 603

Fig 2. Firmness of purple-flesh potato (a), green bean pods (b) and carrots (in phloem tissue (c) and in xylem tissue (d)) at different treatment conditions. CV: cook-vide; SV: sous-vide.

a)
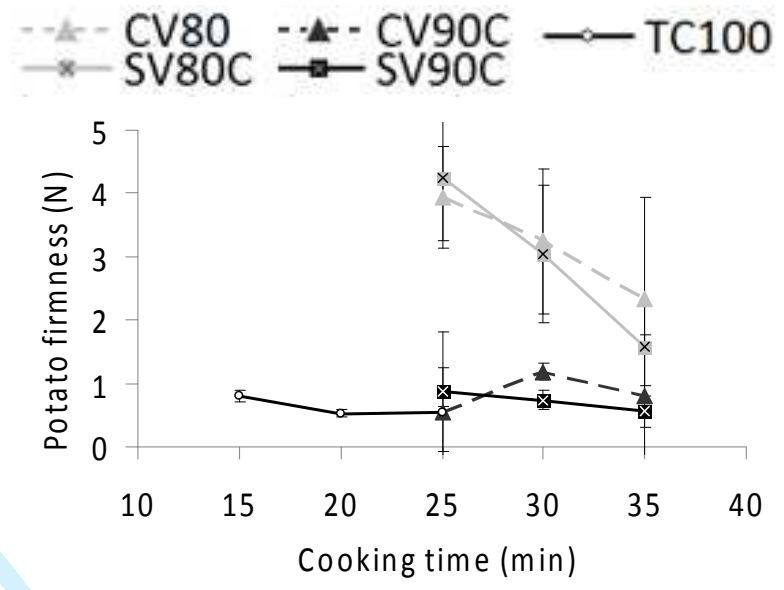

b)

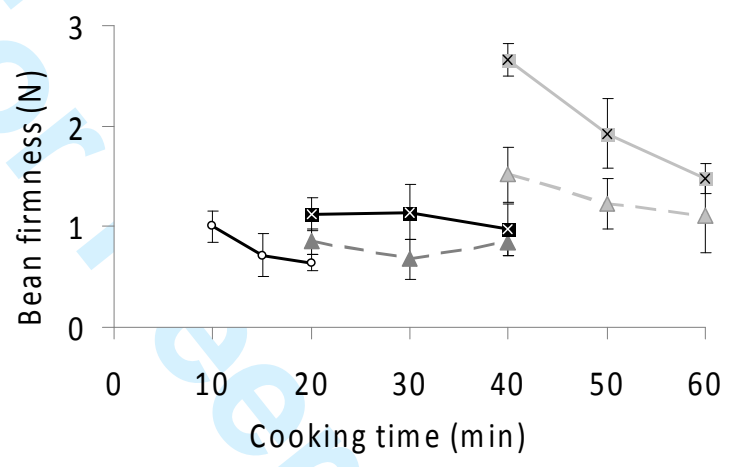

c)

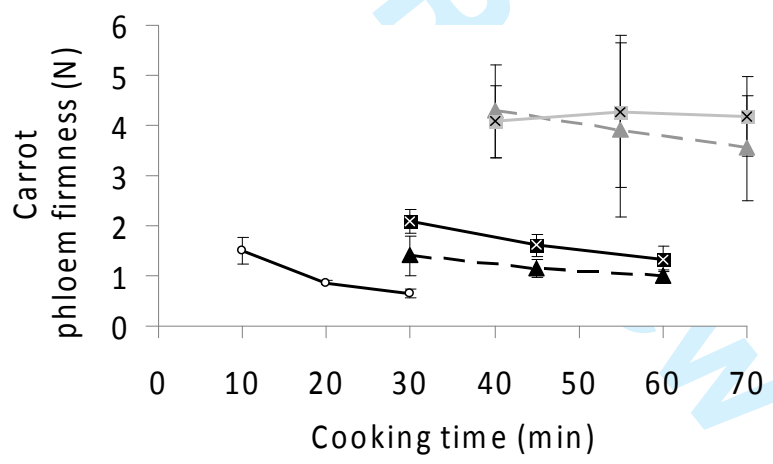

d)

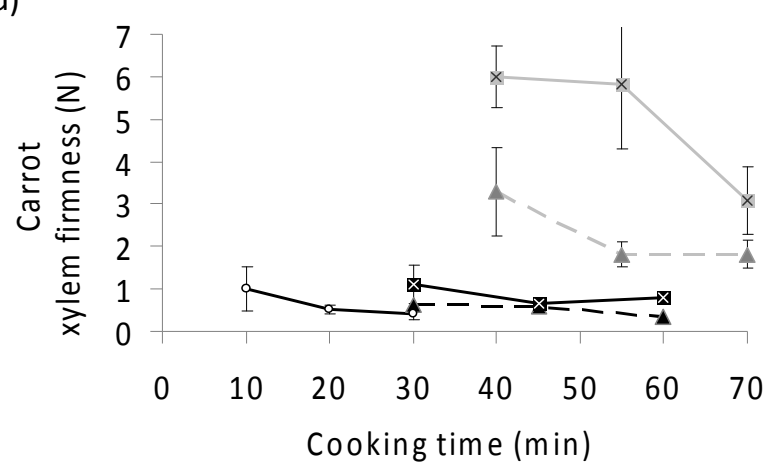


605 Fig. 3. Total difference color $\left(\Delta \mathrm{E}^{*} \mathrm{ab}\right)$ of blue flesh potato (a), green beans pods (b) and carrots (c) of raw 606 and cooked with traditional cooking (TC, at $100{ }^{\circ} \mathrm{C}$ ), cook-vide (at $80^{\circ} \mathrm{C}-\mathrm{CV} 80$ - and $90{ }^{\circ} \mathrm{C}-\mathrm{CV} 90-$ ) and sous607 vide (at $80^{\circ} \mathrm{C}-\mathrm{SV} 80$ - and $90^{\circ} \mathrm{C}-\mathrm{SV} 90-$ ).

608

609

a)

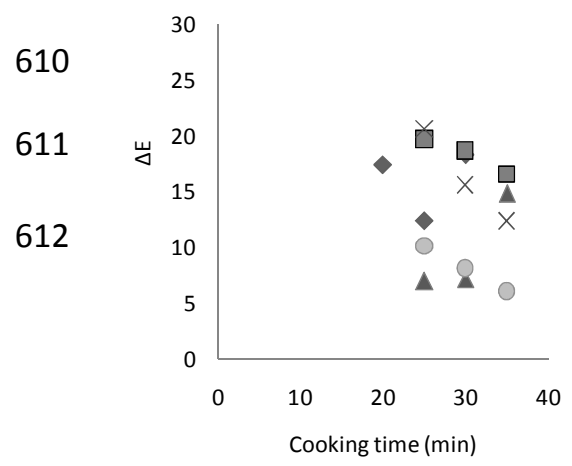

b)

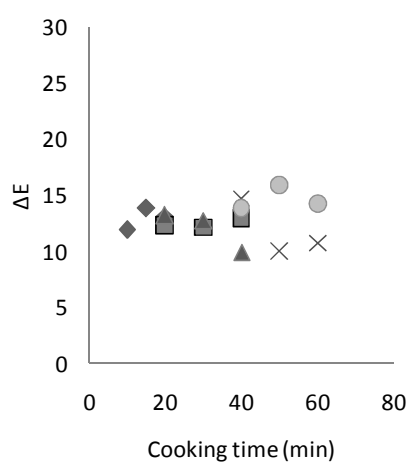

c)

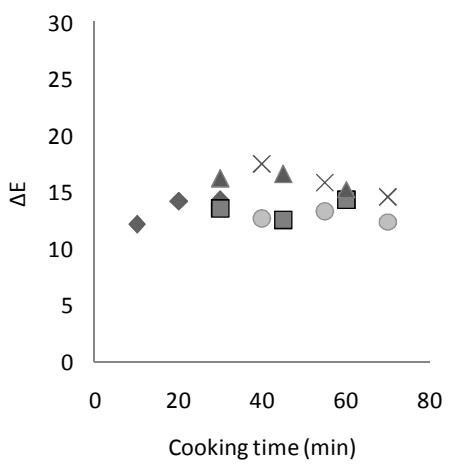

XCV80 빼 CV90 OSV80 \SV90 $\bullet$ TC100 
613

614

615

616

617

Fig. 4. Anthocyanin contents (a) in purple flesh potato (wet weight),ascorbic acid contents (b) in green beans (wet weight) and $\beta$-carotene contents (c) in carrots (wet weight) of raw products and samples cooked with traditional cooking $\left(\mathrm{TC}\right.$, at $100{ }^{\circ} \mathrm{C}$ ), cook-vide (at $80{ }^{\circ} \mathrm{C}-\mathrm{CV} 80$ - and $90^{\circ} \mathrm{C}-\mathrm{CV} 90$-) and sous-vide (at $80^{\circ} \mathrm{C}-\mathrm{SV} 80$ - and $90^{\circ} \mathrm{C}-\mathrm{SV} 90-$ ).
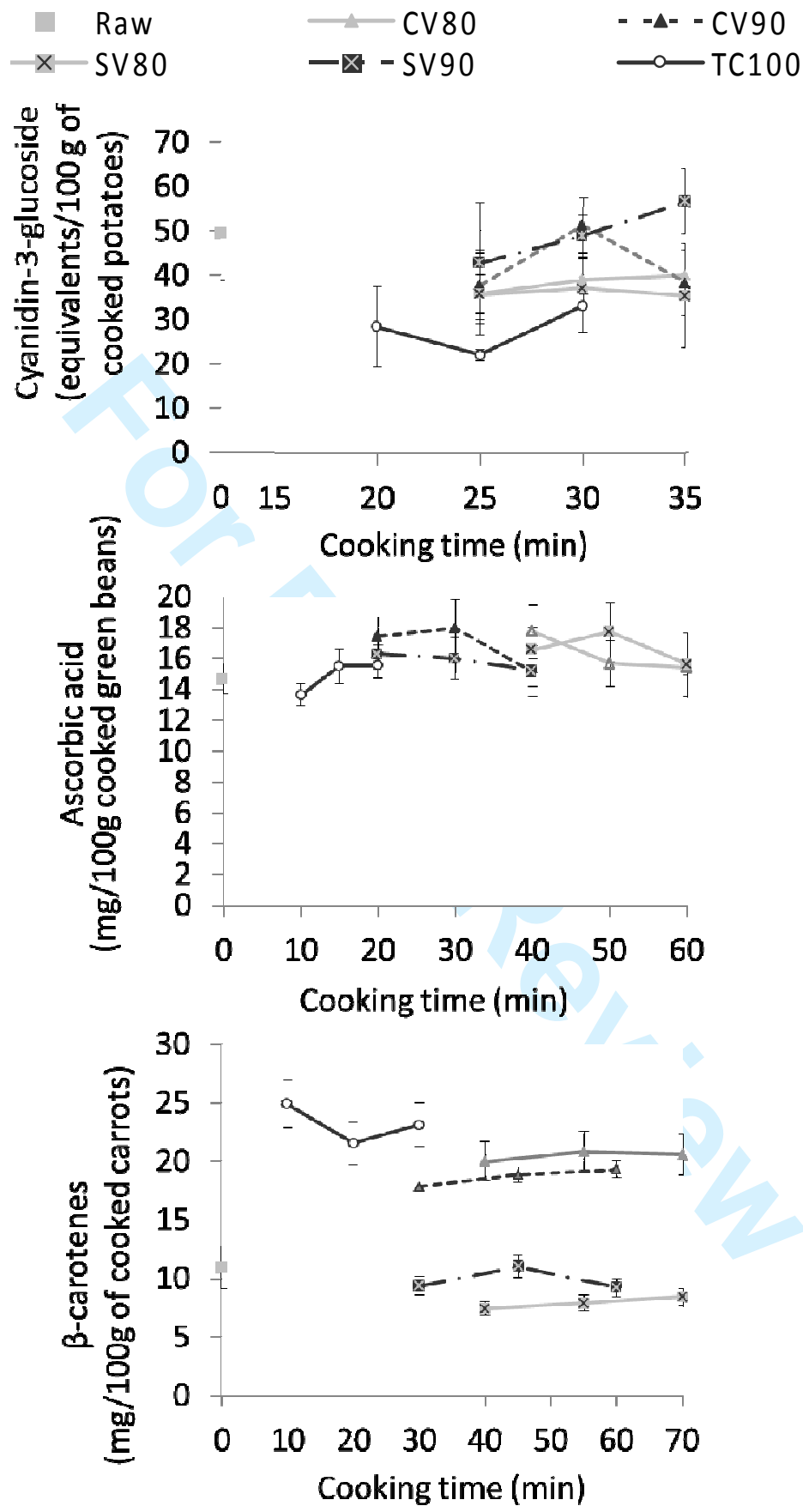

618 
622 Fig. 5. Cryo-scanning electron micrographs (magnification of $x 750$ ) of tissues of purple flesh potato (a), 623 green beans (b) and carrots (c). O: Intracellular organelles; S: Separation between cell membranes and cell 624 wall; J: Intercellular space.

(a)

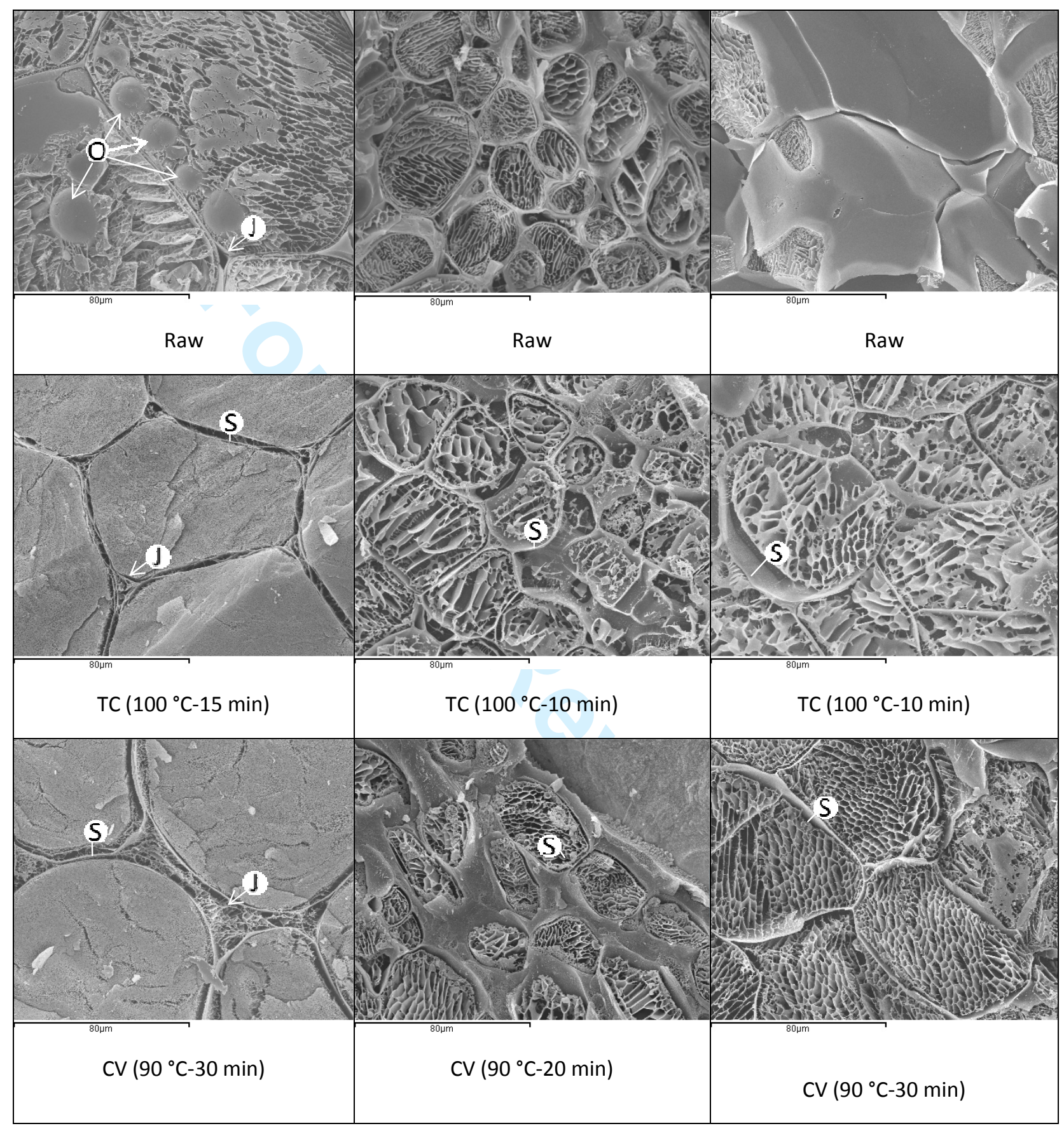




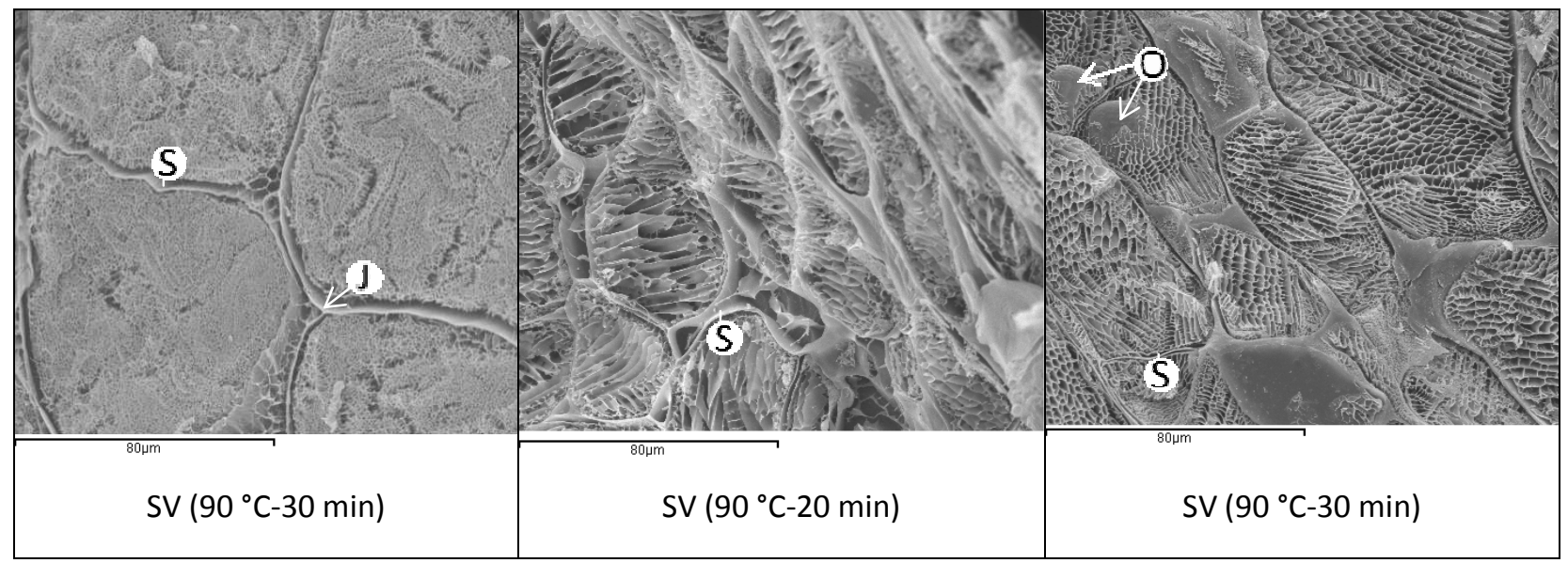

625

626 